\title{
Genes involved in mitochondrial biogenesis and function may not show synchronised responses to mitochondria in shell gland of laying chickens under infectious bronchitis virus challenge
}

\author{
Samiullah Khan ${ }^{1,2}$, Juliet Roberts ${ }^{1}$ and Shu-Biao $\mathrm{Wu}^{1 *}$ [D
}

\begin{abstract}
Background: Egg formation takes place in the oviduct of laying hens over a $24 \mathrm{~h}$ period. Infectious bronchitis virus (IBV) causes pathological lesions in the chicken oviduct. In the current study, mitochondrial counts were determined in three different segments of the oviduct during egg formation in laying chickens challenged with IBV T strain. Nuclear DNA encoded genes that are involved in mitochondrial biogenesis, fission and function were studied in the shell gland of the oviduct undergoing virus multiplication.

Results: In the shell gland, the mitochondrial count was significantly lower $(P<0.05)$ in the challenged group, compared with the control group. However, it did not vary in response to IBV challenge in the isthmus and magnum regions of the oviduct. The gene succinate dehydrogenase complex, subunit A, flavoprotein variant (SDHA) was down-regulated in the shell gland by IBV challenge $(P<0.05)$, while other genes being studied did not show responses to the challenge $(P>0.05)$. Differential expression of the genes was observed at different time-points of egg-shell formation. The expression levels of citrate synthase (CS), cytochrome C, somatic (CYC, S) and sodium-potassium adenosine triphosphatase $\left(\mathrm{Na}^{+}-\mathrm{K}^{+}\right.$ATPase) genes were significantly higher, while those of SDHA and dynamin related protein 1 (Drp1) genes were significantly lower, at $15 \mathrm{~h}$ compared with $5 \mathrm{~h}$ following oviposition of the previous egg. The expression level of peroxisome proliferator-activated receptor gamma coactivator 1-alpha (PGC-1a) did not show significant change at different time-points.
\end{abstract}

Conclusions: It was concluded that IBV T strain infection in laying hens reduced mitochondrial counts only in the shell gland region of the oviduct. The genes involved in mitochondrial biogenesis or function may not show synchronised responses to that of mitochondria in the shell gland of chickens under T strain of IBV challenge.

Keywords: Laying chicken, Mitochondrial function, Infectious bronchitis, Nuclear DNA encoded genes, Chicken oviduct

\footnotetext{
* Correspondence: shubiao.wu@une.edu.au

${ }^{1}$ Animal Science, School of Environmental and Rural Science, University of

New England, Armidale, New South Wales 2351, Australia

Full list of author information is available at the end of the article
}

(c) The Author(s). 2019 Open Access This article is distributed under the terms of the Creative Commons Attribution 4.0 International License (http://creativecommons.org/licenses/by/4.0/), which permits unrestricted use, distribution, and reproduction in any medium, provided you give appropriate credit to the original author(s) and the source, provide a link to the Creative Commons license, and indicate if changes were made. The Creative Commons Public Domain Dedication waiver (http://creativecommons.org/publicdomain/zero/1.0/) applies to the data made available in this article, unless otherwise stated. 


\section{Background}

The infundibulum, magnum, isthmus and shell gland (uterus) contribute to egg formation in laying chickens. Egg-shell formation takes place in the isthmus and shell gland regions, where the former contributes only to shell membrane formation. Egg formation involves the production of steroid hormones, which regulate the proliferation and growth of oviducal epithelial cells throughout the oviduct. For example, the administration of estrogen and/or progesterone leads to massive growth of the epithelia in the oviduct of juvenile hens [1-3]. An egg is composed of egg internal contents and egg-shell. Among the internal contents, albumen is secreted by the magnum and is composed mainly of ovalbumin, muco-proteins and globulins [4]. The shell membranes are synthesized in the isthmus region of the oviduct and contain collagen proteins in its composition [5]. Egg-shell synthesis occurs in the shell gland and is composed mainly of calcium carbonate [6] and shell matrix proteins, such as the ovocalyxin family [5].

Mitochondrion acts as a powerhouse of the cell, where it plays a vital role in cellular metabolism, calcium handling, heme biosynthesis, cell differentiation, apoptosis and aging [7-9]. Mitochondrial count in a cell varies in different cell types $[10,11]$, different organs, the sex and age of an organism $[12,13]$ and physiological and disease conditions $[10,14]$. A higher mitochondrial respiratory capacity and mitochondrial counts have been recorded in more physically active humans $[15,16]$. Similarly, increases in mitochondrial DNA (mtDNA) have been observed during myogenesis in rats [17] and in brown adipocytes of various mammals in response to low temperature [18]. During the cell cycle, mitochondria undergo changes in shape, count and location; however, it is not known how quickly mitochondria divide in metabolically active and inactive cells. In the reproductive track of laying chickens, it is unclear how mitochondria respond to the need of the cells for ATP by either inducing mitochondrial division or accelerating mitochondrial function without division. Cells can respond to alterations in mitochondrial function by up- or down-regulations in the expression of nuclear-DNA encoded gene [19]. Mitochondrial transcription factor A $(m t T F A)$ encodes a protein that in conjunction with nuclear-DNA polymerase $\gamma(\mathrm{POL} \gamma \mathrm{A})$ control mtDNA replication in a cell $[20,21]$. mtDNA replication machinery synthesizes different proteins that include the single-stranded DNA binding protein (mtSSB), the catalytic subunit of DNA POL $\gamma \mathrm{A}$ and processivity factor, the mitochondrial RNA polymerase and the mitochondrial replicative helicase TWINKLE [22, 23]. Dynamin related protein 1 (Drp1 also called DNM1L) is the main regulator of mitochondrial division in a cell, which is oligomerized by mitochondrial division protein 1 (Mdv1) bound to the outer membrane of mitochondria via Mitochondrial fission 1 protein (FIS1) [24-27]. Nuclear genome of the cell encodes proteins essential for mtDNA maintenance and replication [23]. The synthesised proteins are translocated into the mitochondria after their packaging in the cytoplasm. Therefore, expression of genes coded by mtDNA and nuclear genomes are accurately coordinated for regulating the electron transport linked phosphorylation capacity in response to changes in physiological demands of cells [28]. Studies in a single celled green algae (chlorella) [29], HeLa cells (strain- F315) [30] and the opportunistic pathogenic dimorphic yeast (Candida albicans) [31] indicate that increase in total mitochondrial count per cell occurs continuously during the cell cycle. This increase in mitochondrial counts is usually positively correlated with the increase in cell volume. In HeLa and dimorphic yeast cells, mitochondrial count is comprised of approximately $10 \%$ of the total cell volume while, in algae, this value is about $3 \%$ but is constant throughout cell division [29-31].

Citrate synthase $(C S)$ gene encodes an enzyme that is localised in the mitochondrial matrix after being shaped in the ribosome [32]. In mammals, the CS gene has been used extensively as a marker for intact mitochondrial density [33-35]; however, its role has been questioned in studies of developmental stages [36], age of animal [37] and physical activity [38]. CS has been shown to be positively correlated with acute exercise activities in mammalian muscles [39, 40]. Succinate dehydrogenase complex, subunit A $(S D H A)$ gene, encodes a major catalytic subunit of succinate-ubiquinone oxidoreductase, a complex of the mitochondrial respiratory chain. SDHA gene provides instructions for synthesizing one of four parts (subunits) of the succinate dehydrogenase (SDH) enzyme. SDH then participates in both the electron transport chain and the Krebs cycle. Peroxisome proliferator-activated receptor gamma coactivator 1-alpha (PGC-1 $\alpha / P P A R G C 1 A)$ is the master regulator in mitochondrial division [41]. In vitro studies in muscle cells [42], C2C12 myoblasts [43] or in mice cardiac myocytes [44] have shown that PGC-1 $\alpha$ is capable of activating the expression of a cascade of genes involved in mitochondrial synthesis and respiratory function in different types of cells. Therefore, $P G C-1 \alpha$ is mainly involved in mitochondrial energy metabolism and mitochondrial biogenesis. Cytochrome $\mathrm{C}$ somatic (CYC, $S$ ) gene encodes cytochrome $\mathrm{C}$ enzyme that plays a role in the electron transport chain complex in mitochondria and during apoptosis. $\mathrm{Na}^{+}-\mathrm{K}^{+}$ATPase gene encodes an enzyme that is an integral membrane protein which consists of $\alpha$ and $\beta$ subunits [45]. This enzyme plays an essential role in maintaining the transmembrane gradient of $\mathrm{Na}^{+}$ and $\mathrm{K}^{+}$ions in cells [46].

Infectious bronchitis virus (IBV) is a highly contagious avian mucosal pathogen that not only affects layer and broiler chickens but also other avian species worldwide 
[47]. Similar to other coronaviruses, IBV is composed of a small membrane protein (E), the integral membrane protein $(\mathrm{M})$, the nucleoprotein $(\mathrm{N})$ and the spike glycoprotein $(S)[48,49]$. The $S$ protein is composed of two subunits, the S1 (head) and the S2 (stalk) that is responsible for binding to the target cell receptor in host [50,51], while the $\mathrm{N}$ protein induces cell mediated immunity [52]. There is not much information about whether IBV entry and fusion to host cells occurs following endocytosis or at the cell membrane $[51,53]$. Host cell neutral $\mathrm{pH}$ is considered lethal for fusion of the virus particle [54]. Among other host cell surface receptors, sialic acid has been shown to act as a receptor for binding of IBV spike proteins in respiratory, kidney and oviduct epithelia [55-58]. IBV can infect any age of birds; however, the mortality is higher in very young chicks compared with older birds [59]. Mortality rates depend upon viral strain, birds age and immune status of the bird [60]. Among all the field strains of Australian IBV, $\mathrm{T}(\mathrm{N} 1 / 62)$ is considered the most virulent in inducing pathological changes in the tracheal, kidney and oviduct epithelia of laying hens. Infection with IBV in the oviduct leads to various degrees of pathogenesis in the oviduct and reduction in egg production [61-65].

The present study aimed to: a) determine mitochondrial counts in the cells of oviduct segments in laying hens at different time-points of egg formation in relation to the requirement of energy for egg production during IBV challenge; $b$ ) to determine the expression of nuclear DNA encoded genes in the shell gland to gain insights into their responses to IBV infection and time-points of egg-shell formation.

\section{Methods}

\section{Birds rearing}

Day-old Isa-Brown laying chickens were vaccinated with Rispens vaccine for Marek's disease but were not vaccinated for infectious bronchitis. At the University of New England, the chickens were raised in IBV free isolation sheds following strict biosecurity protocol. The birds were reared as per the guidelines of the ISA General Management Guide 2009-10. From the isolation sheds, pullets (18-week old) were moved to cages in an isolated poultry house. During the rearing period, no morbidity or mortality was recorded until the birds were challenged with IBV. Before IBV challenge, an ELISA (ELISA kit, IDEXX Laboratories, Inc., Westbrook, MA, USA) was performed on blood serum of all the chickens. At 35-week of flock age, eggs were processed for egg quality parameters following the method of Samiullah et al. [66]. Chickens were allocated into treatment groups (Table 1 ) by $2 \times 2$ factorial design based on egg-shell colour $\left(\mathrm{L}^{*}\right)$ and egg weight $(\mathrm{g})$ that were not significantly different $(P>0.05)$ among the treatment groups (data not shown).
Table 1 Allocation of birds into various groups for IBV challenge study in the oviduct of laying hens

\begin{tabular}{lll}
\hline Group & Time-point (hr) \\
\cline { 2 - 3 } & 5 & 15 \\
\hline IBV T strain (20 birds) & 10 birds & 10 birds \\
Control (20 birds) & 10 birds & 10 birds
\end{tabular}

Time-point ( $\mathrm{hr}$ ) refers to egg post-oviposition time as determined by video camera. At the time of processing of individual hen, the forming egg was either in the distal magnum/isthmus ( $5 \mathrm{~h}$ time-point) or in the shell gland (15 h time-point)

The hens selected for the virus inoculation were transferred to a separate layer cage house one week before the challenge in order for the chickens to adapt to the new shed and recover from the translocation stress. In both the virus challenge and the control groups, five chickens from each time-point at one time were inoculated intra-occularly with either $10^{7}$ embryo infective dose (E.I.D 50 )/bird of allantoic fluid or mock infected (PBS). The challenged chickens were closely observed for the development of clinical signs of IB [65] and loss of egg-shell colour until days 9-10 post-infection (p.i.). In a separate experiment, the E.I.D 50 dose was calculated from virus being titrated in embryonated SPF-eggs. The incubated eggs were inoculated at day- 9 with $10^{-3}$ to $10^{-8}$ serial dilutions of IBV $\mathrm{T}$ strain $(\mathrm{N} 1 / 62)$ [67]. On day-16 of incubation, the eggs were opened and the number of dead, live or IBV affected embryos recorded after the method of Reed and Muench [68]. The virus infection in the chickens was confirmed through quantitative PCR (in oviduct tissue) and by ELISA of blood plasma samples.

\section{Oviduct tissue collection}

For accuracy of sampling, the oviposition times for individual hens were recorded by video camera. At specific post-oviposition times ( 5 or $15 \mathrm{~h}$ ), hens were euthanized with $\mathrm{CO}_{2}$ gas and approximately $500 \mathrm{mg}$ pieces of tissue from each of the shell gland, isthmus and distal magnum were aseptically collected into RNALater. The tissue samples were stored in $\mathrm{a}-20^{\circ} \mathrm{C}$ freezer until processed for DNA/RNA extraction.

\section{DNA extraction}

For the total genomic (including mitochondrial) DNA extraction from the oviduct tissue (all tissue layers), the TRIsure (Bioline, Australia) protocol was slightly modified for obtaining pure nucleic acids. Briefly, a $100 \mathrm{mg}$ of tissue was thoroughly homogenized in $1 \mathrm{~mL}$ of TRIsure. For obtaining quality DNA/RNA, the TRIsure added samples were maintained on ice and the homogenisation step was also performed in a tube containing ice. For total RNA extraction, after the chloroform step, the transparent upper layer was used (see below). For DNA 
extraction, the remaining middle and bottom layers were thoroughly mixed and further processed. To precipitate DNA, $0.3 \mathrm{~mL}$ absolute ethyl alcohol was added into each sample and the samples were incubated for $3 \mathrm{~min}$ at room temperature. To obtain a DNA pellet, the ethanol precipitated DNA samples were centrifuged for $5 \mathrm{~min}$ at $2000 \times g$ in an Eppendorf centrifuge $\left(4^{\circ} \mathrm{C}\right)$. The resultant DNA pellet was washed with continuous shaking in $1 \mathrm{~mL}$ of $0.8 \mathrm{M}$ sodium citrate (containing $10 \%$ absolute ethanol). The samples were centrifuged as described earlier. Next, the DNA pellet was washed in $1.5 \mathrm{~mL}$ of $75 \%$ ethyl alcohol and the samples centrifuged as described earlier. After maximum ethanol removal, the DNA pellet was dissolved in $100 \mu \mathrm{L}$ TE buffer and the samples centrifuged for $10 \mathrm{~min}$ at $12000 \times g$ to remove any insoluble material. For concentration and purity measurements, the total DNA was analysed in a Nanodrop-8000 (ThermoFisher Scientific, USA). The average $260 / 280$ and $260 / 230$ ratios for individual DNA samples were in the acceptable range (1.8 2.2). The DNA samples were stored at $-20^{\circ} \mathrm{C}$ until used for quantitative PCR assays.

\section{Total RNA extraction and purification}

During DNA extraction, the upper layer after chloroform treatment was processed for total RNA extraction according to the manufacturer's instructions (TRIsure protocol). The RNA was precipitated with $0.5 \mathrm{~mL}$ chilled iso-propanol and the pellet washed with $1.5 \mathrm{~mL}$ of $75 \%$ ethanol. The RNA pellet was dissolved in $100 \mu \mathrm{L}$ of PCR grade water (RNase/DNase free) and processed for RNA purification using an RNeasy Mini Kit (Qiagen, Australia) as per the manufacturer's instructions. The purified total RNA was analysed in a nanodrop as described earlier. RNA quality and concentration were further analysed in an Agilent 2100 Bioanalyzer using the Agilent RNA-6000 Nano Kit as per the manufacturer's protocol. All the samples showed distinct $18 \mathrm{~S}$ and $28 \mathrm{~S}$ bands with an average RIN of $\geq 9.1$. To quantify the viral RNA from the oviduct segments, epithelial scrapings were also processed for total RNA extraction following a partial modification of the method described by Chousalkar et al. [69]. Approximately $1 \mathrm{~g}$ of oviduct scrapings (magnum, isthmus and shell gland segments) was mixed with $1 \mathrm{~mL}$ of sterile PBS, shaken vigorously and centrifuged at $4800 \times g$ for $10 \mathrm{~min}$ at $4{ }^{\circ} \mathrm{C}$. From the supernatant, $200 \mu \mathrm{L}$ was mixed with $1 \mathrm{~mL}$ of TRIsure and total RNA was extracted as per the manufacturer's protocol. The extracted total RNA was used for viral RNA quantification from oviduct tissue scrapings.

\section{Primer design and validation}

The primer sequences shown in Table 2 were designed using NCBI-primer software with the design of at least one primer sequence spanning the exon-intron junction or the amplicon of the primers spanning over two exons with the intron in-between at size of at least $500 \mathrm{bp}$. For sequence specificity, the primers were cross checked in Ensemble Chicken Galgal4, NCBI database using BLASTN and UCSC's Chicken (Gallus gallus) Genome Browser Gateway. Prior to real-time qPCR analysis, the primer specificity and amplification efficiency were determined in serial dilutions $\left(10^{-1}\right.$ to $\left.10^{-8}\right)$ of the purified RNA/DNA. The primer amplification efficiency (\%) was analysed based on the mathematical equation [70]: $\mathrm{E}=10^{(1 / \mathrm{slope})}-1$.

\section{DNA cloning for mitochondrial count quantification}

For mtDNA copy number quantification through qPCR, the $137 \mathrm{bp}$ fragments of each of the GAPDH and ND4 genes were ligated into plasmid vector using the Rapid One Shot chemical transformation protocol of the TOPO TA Cloning Kit for sequencing (ThermoFisher Scientific, Australia) as per the manufacturer's protocol. Next, the recombinant plasmid was transformed into One Shot chemically competent Escherichia coli cells. A $50 \mu \mathrm{L}$ of the cells was plated on Difco Luria-Bertani (LB) Agar (Bacto Laboratories, Australia) and incubated overnight at $37^{\circ} \mathrm{C}$. From the grown colonies, a single colony was enriched in LB broth and incubated overnight at $37^{\circ} \mathrm{C}$. From the cultured broth, $1 \mathrm{~mL}$ was used to extract recombinant plasmid DNA using the PureLink Quick Plasmid Miniprep Kit (ThermoFisher Scientific, Australia) as per the manufacturer's protocol. The eluted recombinant plasmid DNA purity and concentration were analysed in the nanodrop as described earlier. The recombinant plasmid DNA samples were stored at $-20^{\circ} \mathrm{C}$ until used for qPCR assays. To check the amplification efficiencies for the standard curve construction of GAPDH and ND4, qPCR was run on the recombinant plasmid DNA $\left(10^{-2} \sim 10^{-8}\right)$ in a $20 \mu \mathrm{L}$ PCR reaction. The master-mix preparation and qPCR cycling conditions were as per the protocol of the SensiFAST SYBR No-ROX Kit (Bioline, Australia). For standard curve construction, eight different serial dilutions $\left(10^{-2} \sim 10^{-9}\right)$ of the recombinant plasmid DNA were prepared and qPCR amplified. To construct the standard curves for GAPDH and ND4, quantification cycles (Cq) were plotted against $\log _{10}$ copy number of plasmids calculated according to the molecular weight of recombinant plasmids [71]. The amplified PCR products were sequenced by the Australian Genome Research Facility, Australia for confirmation of GAPDH and ND4 fragment inserts into the plasmid vector.

\section{Mitochondria quantification}

For mitochondrial count per cell enumeration, mtDNA copies in a cell were normalised with genomic DNA copies [71, 72]. The SYBR green method of the SensiFAST SYBR No-ROX Kit (Bioline, Australia) was followed for 


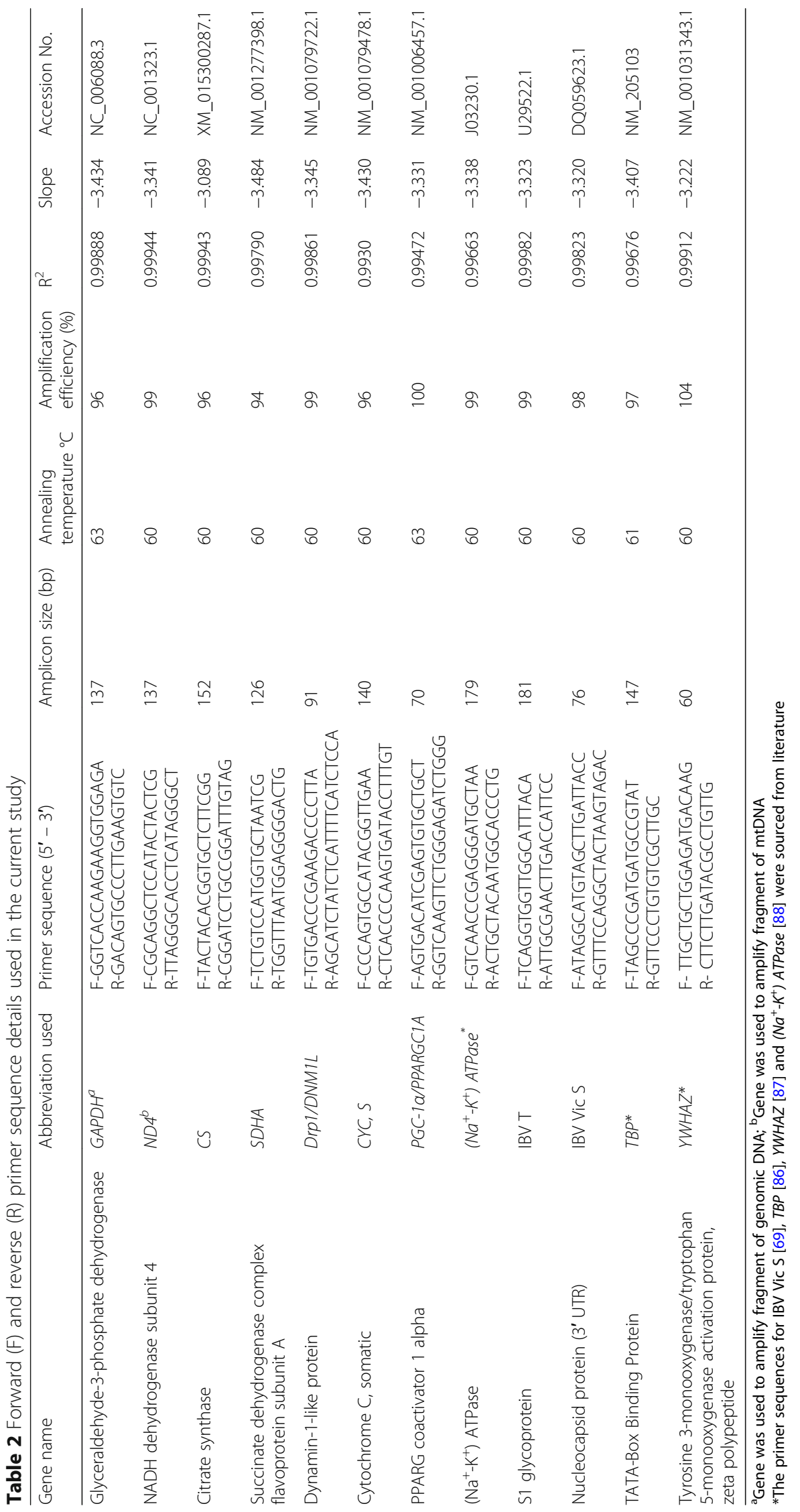


qPCR as per the manufacturer's protocol. The qPCR was performed in a Rotor-Gene Q thermocycler (Qiagen, Australia) in a total volume of $20 \mu \mathrm{L}$ master-mix reaction. The reaction consisted of $10 \mu \mathrm{L} 2 \times$ SensiFAST SYBR No-ROX mix, $6.4 \mu \mathrm{L}$ RNase-free PCR grade water, $0.8 \mu \mathrm{L}$ each of the primers and $2 \mu \mathrm{L}$ of the DNA $\left(10^{-2}\right.$ dilution of the extracted DNA). To rule out external contamination, a negative control reaction with no DNA template was included in each qPCR run. For standard curve construction and mitochondrial count per cell calculation, recombinant plasmid DNA dilutions $\left(10^{-2} \sim 10^{-9}\right)$ were included in the respective qPCR runs. The conditions for a 2-step qPCR were: denaturation at $95^{\circ} \mathrm{C}$ for $3 \mathrm{~min}, 40$ cycles of denaturation at $95^{\circ} \mathrm{C}$ for $5 \mathrm{~s}$ and annealing and extension at $60^{\circ} \mathrm{C}$ or $63^{\circ} \mathrm{C}$ for $30 \mathrm{~s}$ (Table 2). Fluorescent data were acquired at the end of each annealing/extension step during qPCR cycles (40). The mtDNA copy number per cell in the magnum, isthmus and shell gland was calculated according to the equation: (mtDNA copies)/(gDNA copies/2) [71].

\section{Relative gene expression analysis}

For the relative expression of gene studies, shell gland RNA samples were run in duplicate with the inclusion of appropriate internal controls. The qPCR master-mix was prepared as per the manufacturer's protocol of SensiFAST SYBR Lo-ROX One-Step RT-PCR Kit (Bioline, Australia). The PCR final $20 \mu \mathrm{L}$ volume reaction contained $10 \mu \mathrm{L}$ of $2 \times$ SensiFAST SYBR low-Rox one-step mix, $0.4 \mu \mathrm{L}$ of RiboSafe RNase inhibitor, $0.2 \mu \mathrm{L}$ of reverse transcriptase, $0.8 \mu \mathrm{L}$ of each of the forward and reverse primers, $3.8 \mu \mathrm{L}$ RNase-free PCR grade water and $4 \mu \mathrm{L}$ of RNA template $\left(10^{-2}\right.$ dilution). Using a QIAgility robotic, the reaction volume was distributed into Rotor-Gene Disc 100 (Qiagen, Australia) and run in a Rotor-Gene Q thermal cycler. The two-step PCR conditions were: reverse transcription at $45^{\circ} \mathrm{C}$ for $10 \mathrm{~min}$, polymerase activation and denaturation at $95^{\circ} \mathrm{C}$ for $2 \mathrm{~min}, 40$ cycles of denaturation at $95^{\circ} \mathrm{C}$ for $5 \mathrm{~s}$ and annealing and extension at $60^{\circ} \mathrm{C}, 61^{\circ} \mathrm{C}$ or $63^{\circ} \mathrm{C}$ (according to Table 2) for $20 \mathrm{~s}$. The fluorescent data collection, melting curve analysis and amplification efficiency calculation were performed as described previously.

\section{Viral RNA quantification from oviduct tissue}

IBV $\mathrm{T}$ strain (kindly provided by CSIRO, Geelong, Australia) was cultured in 11-day-old SPF embryonated eggs and allantoic fluid was harvested at day-16 of incubation. Viral RNA was extracted from the allantoic fluid using TRIsure as per the manufacturer's protocol. A 181 bp fragment of viral RNA was amplified using the SensiFAST SYBR Lo-ROX One-Step RT-PCR Kit as per the manufacturer's instructions and cloned (using Rapid One Shot chemical transformation protocol of TOPO
TA Cloning Kit for sequencing) into a plasmid vector for standard curve construction. Details of the cloning method have been described in a previous section. A standard curve was constructed from 10-times serial dilutions $\left(10^{-2} \sim 10^{-9}\right)$ of recombinant plasmid DNA cloned with $181 \mathrm{bp}$ fragment of IBV T strain. Approximately $1 \mu \mathrm{g}$ RNA from individual samples extracted from the magnum, isthmus and shell gland whole tissue (all tissue layers) or mucosal scrapings was reversely transcribed into cDNA using the QuantiTect Reverse Transcription Kit (Qiagen, Australia). Quantitative PCR was performed with the SYBR green method using the SensiFAST SYBR No-ROX Kit. Quantitative PCR reaction was performed in a total volume of $20 \mu \mathrm{L}$ in duplicate on a Rotor-Gene Q thermal cycler and cloned plasmid DNA was included in the same run as standards. The cloned plasmid DNA with insert was calculated as number of copies per $\mu \mathrm{L}$ in six different dilutions for standard curve construction. Plasmid copy number was calculated based on the concentration of plasmid DNA and its molecular weight [71]. Individual sample amplicons from all the three segments of the oviduct were run in the Bioanalyzer as described earlier, to assess the specificity and size of the virus nucleic acid fragment. Viral load was calculated as cDNA copies per $\mu \mathrm{L}$ of PCR reaction volume multiplied by the total reaction volume, RNA elution volume and weight of the tissue used for RNA extraction. Viral load was expressed as viral cDNA copy number per gram of oviduct tissue.

\section{Statistical analysis}

To determine the mitochondrial count per cell, the mtDNA copies per cell were analysed in Statview software (SAS Institute Inc., Version 5.0.1.0) taking the time-point and virus challenge as main effects. The statistical significance $(P<0.05)$ between mean values was determined by the Tukey-Kramer test. For gene expression data analysis, raw $\mathrm{Cq}$ values were analysed in qbase+ software version 3.0 against TBP and $Y W H A Z$ as reference genes [73]. The analysis was based on relative expression $\left(2^{-\Delta \Delta C q}\right)$ using gene specific amplification efficiencies [74-76]. To determine the effect of time-point and IBV challenge, from the qbase+, normalised relative quantities (NRQ) were exported and analysed in Statview Version 5.0.1.0 (SAS Institute Inc., 1998) using one- and two- way ANOVA. Level of significance $(P<0.05)$ between the mean values was determined by Tukey-Kramer test.

\section{Results}

All the primers used in this study were specific in amplifications of the expected products (Fig. 1). The amplification efficiency of the primers ranged from 94 to $104 \%$ (Table 2). 


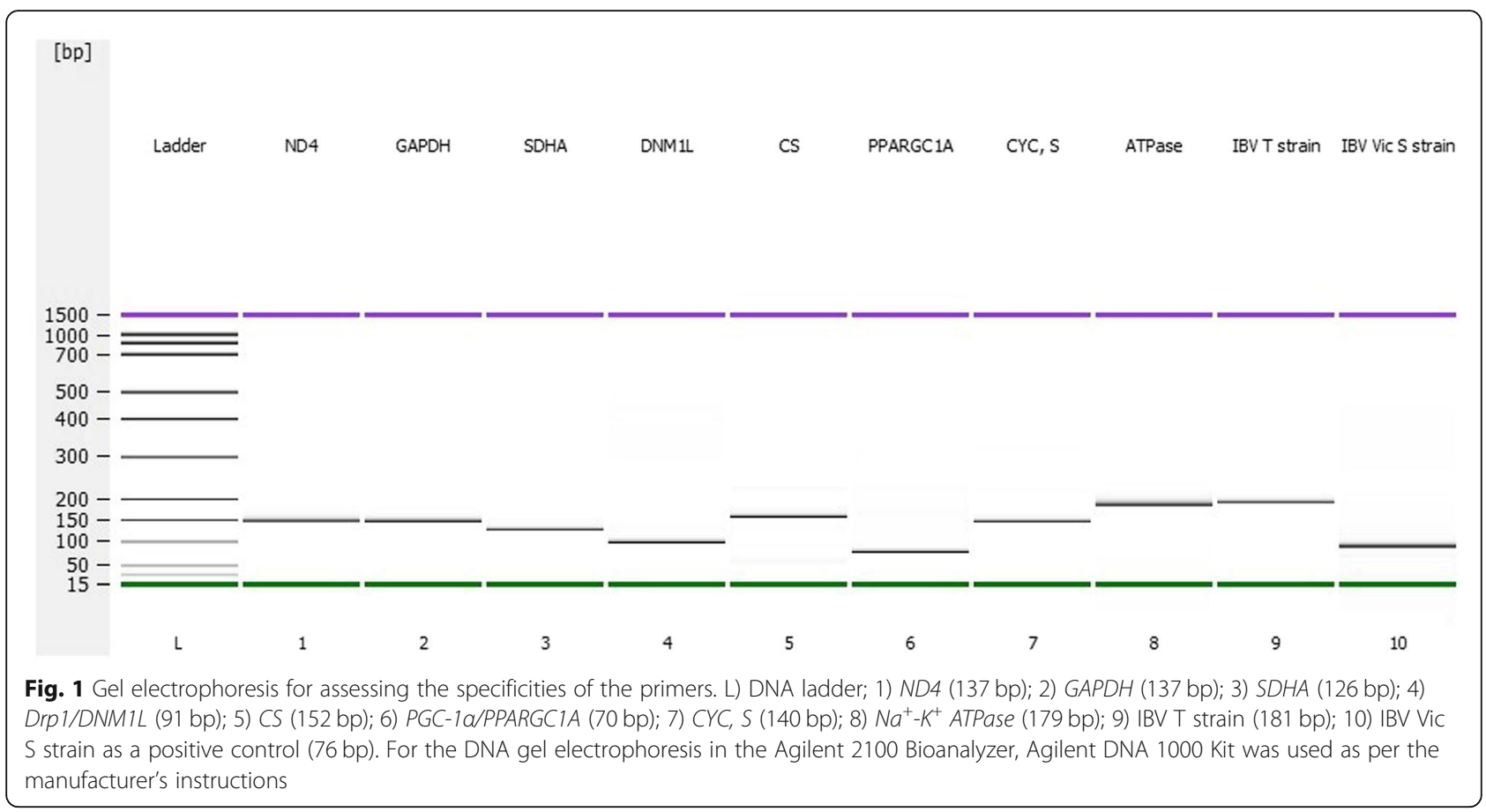

\section{Viral RNA quantification from oviduct}

IBV T RNA was not detectable in any of the three segments of the oviduct (all tissue layers) samples processed for real-time qPCR. However, viral RNA was detected in the shell gland epithelial scrapings. All samples from challenged birds were positive with a mean viral load of approximately $3.55 \times 10^{6}$ copies per gram of shell gland tissue. Viral RNA was not detected in the epithelial scrapings of the magnum and isthmus segments of the oviduct of any of the challenged birds. A significantly higher titre of antibodies for the challenged birds in the ELISA test confirmed that the virus multiplied and caused a significant immune response in the challenged birds (Fig. 2). During the post-challenge period, all infected birds showed characteristic clinical signs of IB. No viral RNA was detected in the control birds as expected.

\section{Mitochondrial quantification}

The mitochondrial count in the shell gland region of the oviduct was significantly lower $(P<0.05)$ in the IBV T strain challenged group compared with the control group (Fig. 3a). IBV T challenge did not significantly affect mitochondrial counts in the isthmus and magnum regions of the oviduct (Fig. 3b, c). The mean mitochondrial count (per cell) was not significantly affected $(P>0.05)$ by time-points of egg formation in any of the three segments of the oviduct (Fig. 3). There was no significant interaction between the time-point and IBV $\mathrm{T}$ strain challenge for mitochondrial counts in the shell gland, isthmus and magnum regions of the oviduct.

\section{Effect of IBV challenge and time-point on gene expression in the shell gland tissue}

Significant interactions $(P<0.05)$ between IBV challenge and time-point of egg-shell formation were observed for the expression of SDHA and $\mathrm{Na}^{+}-\mathrm{K}^{+}$ATPase (Table 3; Fig. 4). The relative expression level of $S D H A$ was significantly lower in the virus challenged groups compared with the control group at the $5 \mathrm{~h}$ time-points, whereas this effect was not observed at the $15 \mathrm{~h}$ time-point of egg-shell formation. The relative expression level of $\mathrm{Na}^{+}-\mathrm{K}^{+}$ATPase was significantly lower in the virus challenged compared with the control group at the $15 \mathrm{~h}$ time-point, whereas at the $5 \mathrm{~h}$ time-point, this effect was not significant (Fig. 4a, b). The relative expression levels of all of the genes except the $S D H A$ were not significantly affected $(P>0.05)$ by IBV challenge (Table 3$)$. The expression levels of all the genes except $P G C-1 \alpha$ were significantly affected by time-point of egg-shell formation. The expression levels of $C S, C Y C, S$ and $\mathrm{Na}^{+}-\mathrm{K}^{+}$ATPase genes were significantly higher, while those of SDHA and Drp 1 genes were significantly lower, at the $15 \mathrm{~h}$ compared with the $5 \mathrm{~h}$ time-point of egg-shell formation (Table 3 ).

\section{Discussion}

We investigated the mitochondrial counts in three different segments of the oviduct of laying hens challenged with IBV T strain, at two stages of egg formation. A significantly lower mitochondrial count in the shell gland of challenged hens suggests that the virus had a greater effect on this region, as compared with the isthmus and magnum segments of the oviduct. A greater severity of 


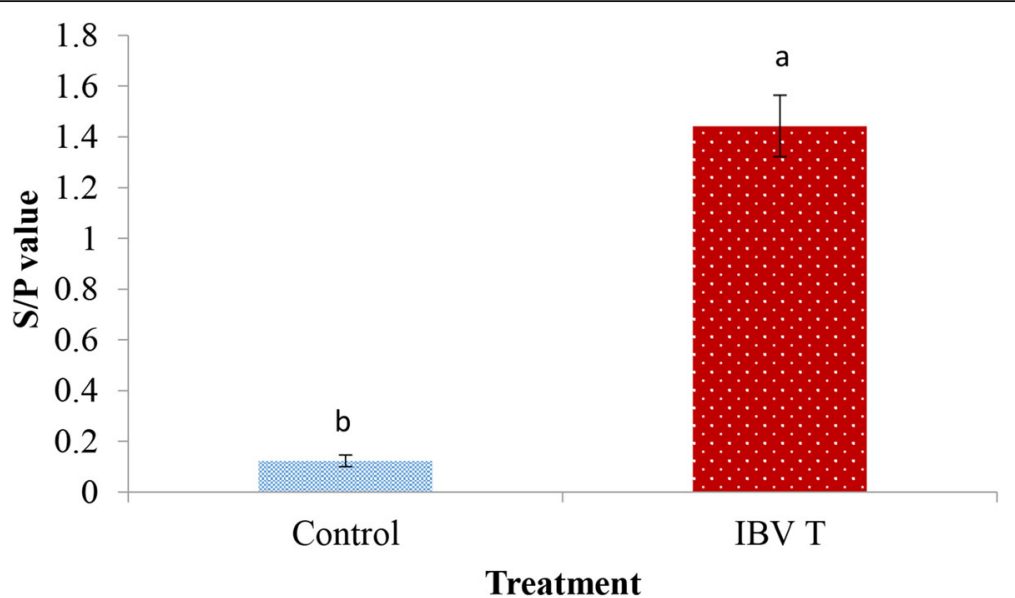

Fig. 2 Antibody titre of the control and challenged hens on days 9-10 post-infection. The antibody titre was calculated as per the protocol of the Infectious Bronchitis Virus Antibody Test Kit (IDEXX Laboratories). According to the kit protocol, Sample/Positive (S/P) ratio > 0.20 shows antibody level positive for IBV. Bars represent standard deviation. Superscripts $\left({ }^{\mathrm{a}, \mathrm{b}}\right)$ show significant differences

pathological lesions caused by IBV $\mathrm{T}$ in the isthmus and shell gland segments, compared with the magnum, has been reported [77]. The data presented here showed that IBV $\mathrm{T}$ infection significantly reduced the mean mitochondrial count only in the shell gland tissue of oviduct. Although the virus seemed to have caused more effects in the shell gland, the reduced mitochondrial count could not be correlated with the expression levels of most of the genes studied except for $S D H A$. It is possible that virus multiplication in the shell gland tissue might compromise the pathways involving the synthesis of SDHA protein. Generally, viral replication alters mitochondrial

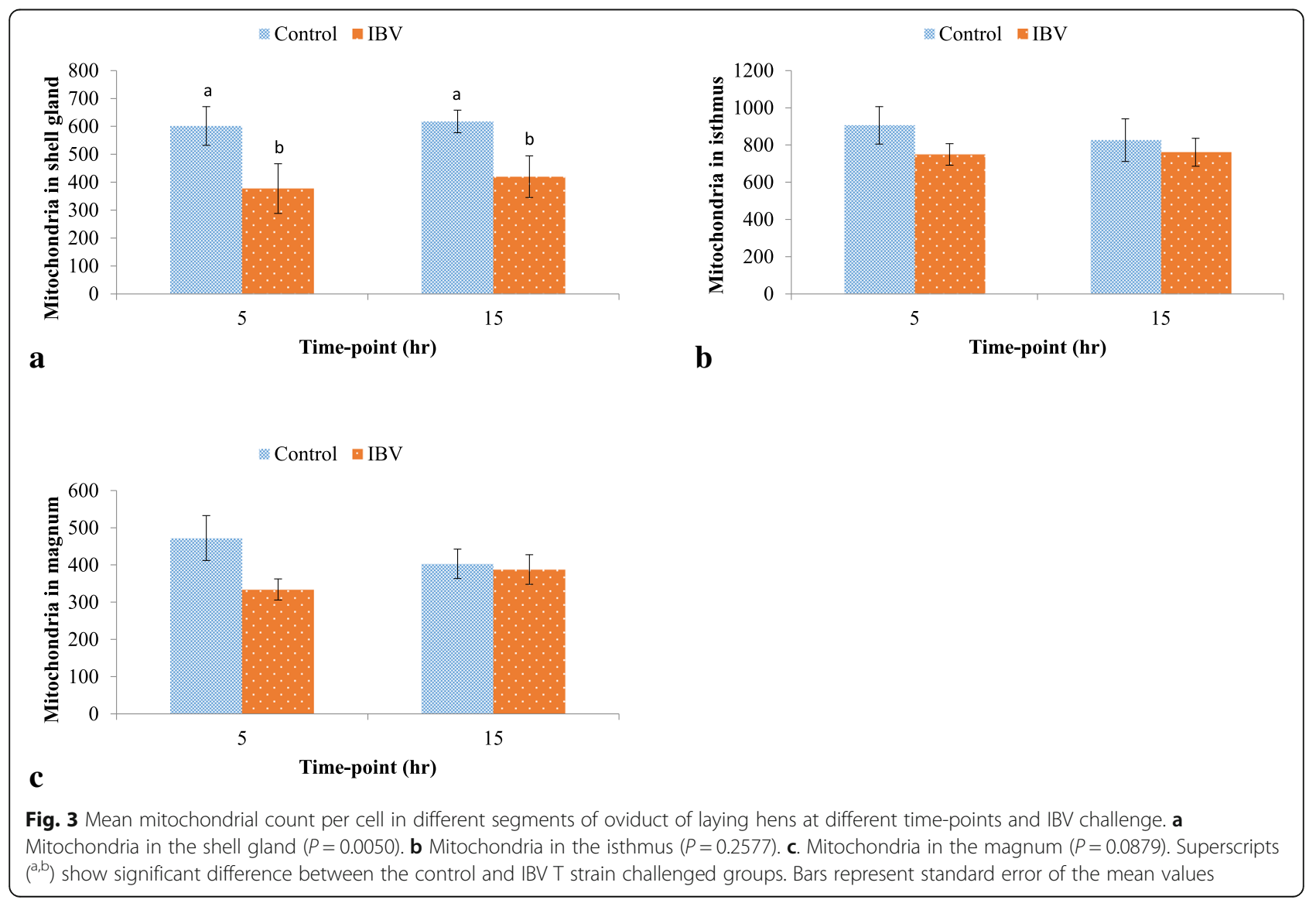


Table 3 Relative expression stabilities of genes in the shell gland of laying hens challenged with IBV

\begin{tabular}{|c|c|c|c|c|c|c|c|}
\hline \multirow[t]{3}{*}{ Gene } & \multicolumn{4}{|l|}{ Group } & \multicolumn{3}{|l|}{$P$ value } \\
\hline & \multicolumn{2}{|l|}{ Virus challenge } & \multicolumn{2}{|l|}{ Time-point (hr) } & \multirow[t]{2}{*}{ Virus challenge } & \multirow[t]{2}{*}{ Time-point } & \multirow[t]{2}{*}{ Interactio } \\
\hline & Yes & No & 5 & 15 & & & \\
\hline$\overline{C S}$ & $1.125 \pm 0.097$ & $1.050 \pm 0.096$ & $0.892 \pm 0.092^{y}$ & $1.283 \pm 0.080^{x}$ & 0.5522 & 0.0032 & 0.7135 \\
\hline SDHA & $0.966 \pm 0.042^{b}$ & $1.079 \pm 0.054^{\mathrm{a}}$ & $1.154 \pm 0.026^{x}$ & $0.891 \pm 0.050^{y}$ & 0.0343 & $<0.0001$ & 0.0188 \\
\hline Drp1 & $1.066 \pm 0.063$ & $0.993 \pm 0.053$ & $1.191 \pm 0.044^{x}$ & $0.868 \pm 0.047^{y}$ & 0.2619 & $<0.0001$ & 0.7039 \\
\hline$P G C-1 a$ & $1.025 \pm 0.053$ & $1.019 \pm 0.049$ & $1.089 \pm 0.062$ & $0.956 \pm 0.030$ & 0.9273 & 0.0671 & 0.9236 \\
\hline$C Y C, S$ & $0.959 \pm 0.025$ & $1.041 \pm 0.021$ & $0.829 \pm 0.037^{y}$ & $1.247 \pm 0.049^{x}$ & 0.1900 & $<0.0001$ & 0.5145 \\
\hline $\mathrm{Na}^{+}-\mathrm{K}^{+}$ATPase & $1.123 \pm 0.134$ & $1.237 \pm 0.165$ & $0.692 \pm 0.077^{y}$ & $1.668 \pm 0.120^{x}$ & 0.3916 & $<0.0001$ & 0.0087 \\
\hline
\end{tabular}

Values are normalised relative quantities (NRQ) to the mean expression level of all the samples \pm S.E. Superscripts (a,b) across the row indicate significant difference between the virus challenged and control groups. Superscripts $\left({ }^{x, y}\right)$ across the row indicate significant difference between the 5 and $15 \mathrm{~h}$ time-points of egg-shell formation. In each group at each time-point, there were 10 samples processed for qPCR assay

permeability transition pore, oxidative balance, mitochondrial membrane potential, electron transport and energy production at the cellular level [78]. It is not clear how IBV $\mathrm{T}$ challenge led to the reduction of mitochondrial counts in the cells; however, in previous studies, degenerated mitochondria in IBV infected cells of shell gland tissue of laying hens have been recorded [64]. In the current study, it seems that the viral load in the shell gland tissue was very low at days 9-10 p.i. and therefore was not detectable in the shell gland tissue containing all tissue layers. However, the mean viral load was $3.55 \times 10^{6}$ copies per gram in the epithelial mucosa (epithelial scrapings) of the shell gland region of the oviduct, indicating that shell gland had succumbed to viral infection particularly in the epithelial layer.

Based on the lack of significant differences in mitochondrial count in the cells between the challenged and control groups for the magnum and isthmus, we focused further on shell gland tissue and studied the expression level of genes involved in mitochondrial density, biogenesis and fission. The lack of any significant difference in the relative expression levels of all of the genes except $S D H A$, between the control and IBV $\mathrm{T}$ challenged groups, may indicate that mitochondrial function may have been enhanced and thus overall egg quality may not have been affected by fewer mitochondria in the shell gland cells of IBV $\mathrm{T}$ infected hens. SDHA functions in mitochondrial complex II, a part of the citric acid cycle and electron transport chain. A significantly lower expression level of the $S D H A$ in the infected group correlates with the lower number of mitochondria. However, to confirm this correlation, further research is needed as the remaining genes studied were not affected by the virus challenge. It also seems that the virus effect on the expression level of SDHA was not consistent, as the mRNA was significantly lower in the virus challenge group at the $5 \mathrm{~h}$ but not the $15 \mathrm{~h}$ time-point. CS enzyme activity has been widely used as a marker for intact mitochondrial density. The activity of CS was $42 \%$ higher in the leg muscle of dominant versus subordinate male red jungle fowl, with no differences in overall muscle mass [79]. In the current study, there was a significantly higher level of CS mRNA at the $15 \mathrm{~h}$ time-point implying that mitochondrial density was higher at this time-point; however, this was not the case as the mitochondrial counts were not significantly different between the 5 and $15 \mathrm{~h}$ time-points of egg-shell

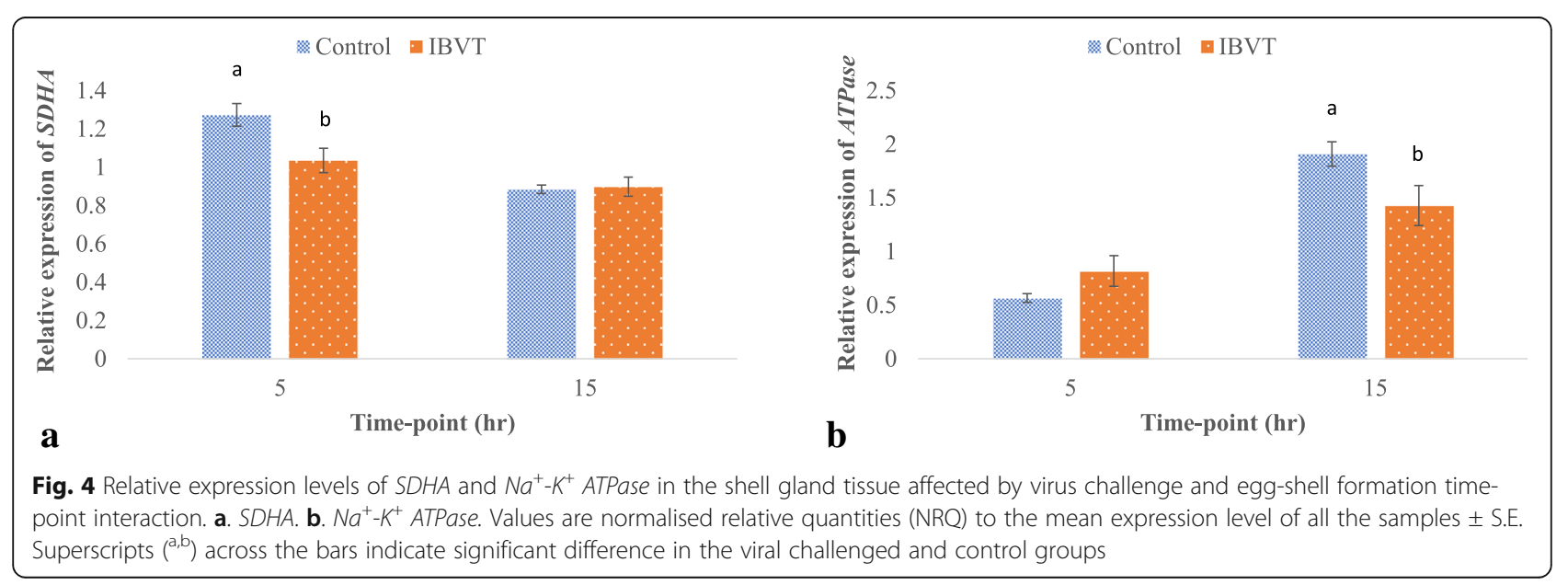


formation. The protein encoded by the CS gene is a Krebs cycle enzyme that catalyses the synthesis of citrate from acetyl coenzyme A and oxaloacetate. The temporal relationships between mitochondrial biogenesis and the expression level of the genes are not clear and thus it is difficult to relate directly the expression level of such genes with mitochondrial counts at different time-points of egg-shell formation.

PGC-1 $\alpha$ protein is a nuclear encoded protein that is localised both in the nucleus and cytoplasm [80]. In mammals, the expression of $P G C-1 \alpha$ is prominent in tissues with high demands for energy [81, 82] and the mRNA level is induced in conditions such as physical exercise, fasting and exposure to cold [82]. Increase in PGC- $1 \alpha$ protein is sufficient to induce cellular pathways important for mitochondrial biogenesis and energy metabolism [43, 44]. Mitochondrial content and oxidative capacity are different in different cells and are regulated by energy demand of a cell [83]. In a study of adenovirus infected SAOS-2 cells, the mitochondrial proteins induced by $P G C-1 \alpha$ regulation resulted in increased mitochondrial content in the cells [83] measured $48 \mathrm{~h}$ after infection. In the current study, the expression level of $P G C-1 \alpha$ was not affected by viral infection and time-points of egg-shell formation. The expression level of PGC-1 $\alpha$ cannot be correlated with mitochondrial counts as the virus challenge reduced the mitochondria at both 5 and $15 \mathrm{~h}$ time-points of egg-shell formation. It seems that a lower number of mitochondria may not necessarily induce the up-regulation of $P G C-1 \alpha$ in cells undergoing virus multiplication. Drp1 is a nuclear encoded protein that plays an important role in the fission of the outer mitochondrial membrane. In healthy cells, fission and fusion events occur to regulate mitochondrial morphology [84]. Once again, the higher expression level of Drp1 at $15 \mathrm{~h}$ compared with the $5 \mathrm{~h}$ time-point cannot be clearly linked with higher activities of mitochondrial fission and/or fusion as most of the genes studied did not show a clear pattern of change with lower mean mitochondrial counts in IBV $\mathrm{T}$ challenged groups. Also, the mitochondrial counts were significantly lower at both 5 and $15 \mathrm{~h}$ time-points in the challenge groups, whereas no expression change of Drp1 was observed upon virus challenge during egg-shell formation. This suggests that having a lower number of mitochondria in a cell may not necessarily relate to the expression level of Drp1. We consider that a spatio-temporal investigation is needed to understand the response of nuclear DNA encoded genes to mitochondrial biogenesis and fission in cells undergoing virus multiplication possibly through immunohistochemistry assays.

The objective of $\mathrm{Na}^{+}-\mathrm{K}^{+}$ATPase quantification was to understand cell membrane potential level in the control and IBV $\mathrm{T}$ challenged groups and at two different timepoints of egg-shell formation. $\mathrm{Na}^{+}-\mathrm{K}^{+}$ATPase is involved in maintaining membrane excitation potential, tight junction polarity and vectorial transport in cells (reviewed in Rajasekaran et al., [85]). A higher expression level of $\mathrm{Na}^{+}-\mathrm{K}^{+}$ATPase at $15 \mathrm{~h}$ compared with the $5 \mathrm{~h}$ time-point is an indication of higher cellular activity of the shell gland tissue during the formation of the egg-shell. A lack of significant difference in the expression level of $\mathrm{Na}^{+}-\mathrm{K}^{+}$ATPase between the control and IBV T challenged groups indicates that viral multiplication in the cells did not alter the normal function of $\mathrm{Na}^{+}-\mathrm{K}^{+}$ATPase and that the cells in both the groups were functioning similarly. However, an interaction of time-point and virus challenge indicated that the expression level of $\mathrm{Na}^{+}-\mathrm{K}^{+}$ATPase was significantly affected by viral multiplication when the egg-shell formation was at its peak in the shell gland. A significant interaction between the time-point and virus challenge for $S D H A$ and $\mathrm{Na}^{+}-\mathrm{K}^{+}$ ATPase indicates that the virus challenge downregulates these genes only at certain stages of egg-shell formation when the expression of the genes is high, at $5 \mathrm{~h}$ for $S D H A$ but at $15 \mathrm{~h}$ for $\mathrm{Na}^{+}-\mathrm{K}^{+}$ATPase.

\section{Conclusions}

Taken together, the results of the current study show that the IBV $\mathrm{T}$ strain challenge in laying hens significantly lowered the mean mitochondrial counts only in the shell gland part of oviduct. Furthermore, the expression levels of the nuclear DNA encoded genes that are involved in mitochondrial biogenesis and/or function could not be clearly correlated with lower mean mitochondrial count and mitochondrial biogenesis. A significant difference in the expression levels of most of the genes at two different time-points of egg-shell formation showed that the mitochondrial function was more affected by egg-shell formation stages than by the viral multiplication in the cells. Further investigation is required to determine the actual turnover of mitochondria in metabolically active organs, such as laying hen oviduct, in normal and pathological conditions, and spatio-temporal relationship between mitochondrial count and expression of genes coding mitochondrial biogenesis related proteins.

\section{Abbreviations \\ CS: Citrate synthase; CYC, S: Cytochrome C, somatic; Drp1: Dynamin related protein 1; gDNA: genomic DNA; IBV: Infectious bronchitis virus; mtDNA: mitochondrial DNA $\mathrm{Na}^{+}-\mathrm{K}^{+}$ATPase: sodium-potassium adenosine triphosphatase; PGC-1a: Peroxisome proliferator-activated receptor gamma coactivator 1-alpha; SDHA: Succinate dehydrogenase complex, subunit A, flavoprotein variant}

\section{Acknowledgements}

We thank Dr. Sandra Sapats at the Australian Animal Health Laboratory, CSIRO, Geelong, Australia for providing the infectious bronchitis virus T (N1/62) strain.

\section{Funding}

This study was funded by the Australian Egg Corporation Limited, under grant number AECL 1 UN121 to Juliet Roberts. The funding body was not involved in the collection, analysis and interpretation of data and in writing the manuscript. 


\section{Availability of data and materials}

All the data have been presented in this article. Access to the raw data can be provided through request. This study did not involve the generation of NGS sequences.

\section{Authors' contributions}

S.K. and J.R. framed the hypotheses, designed and performed the animal trial. S.K. analysed and interpreted data and drafted the manuscript. J.R. monitored the overall research project and critically revised the manuscript. S-B.W. designed gene expression experiments, analysed and interpreted the data and drafted the manuscript. All the authors read and approved the manuscript for publication.

\section{Ethics approval and consent to participate}

The animal trial was approved by the University of New England, Animal Ethics Approval Committee under Authority No. AEC15-118. The experimental protocol complied with the guidelines specified in the Australian Code for the Care and Use of Animals for Scientific Purposes 8th edition 2013. This study did not involve the use of human data or tissue.

\section{Consent for publications}

The authors declare no consent for publishing the data originated from this study.

\section{Competing interests}

The authors declare that they have no competing interests.

\section{Publisher's Note}

Springer Nature remains neutral with regard to jurisdictional claims in published maps and institutional affiliations.

\section{Author details}

${ }^{1}$ Animal Science, School of Environmental and Rural Science, University of New England, Armidale, New South Wales 2351, Australia. ${ }^{2}$ Present address: School of Animal and Veterinary Sciences, The University of Adelaide, Roseworthy, South Australia 5371, Australia.

\section{Received: 15 May 2018 Accepted: 21 March 2019}

\section{Published online: 01 April 2019}

\section{References}

1. Palmiter RD, Wrenn JT. Interaction of estrogen and progesterone in chick oviduct development III. Tubular gland cell cytodifferentiation. J Cell Biol. 1971:50:598-615.

2. Kohler PO, Grimley PM, O'malley BW. Estrogen-induced cytodifferentiation of the ovalbumin-secreting glands of the chick oviduct. J Cell Biol. 1969:40:8-27.

3. Oka T, Schimke RT. Interaction of estrogen and progesterone in chick oviduct development II. Effects of estrogen and progesterone on tubular gland cell function. J Cell Biol. 1969:43:123-37.

4. Majumder K. Composition and properties of egg white. In: Roberts JR, editor. Achieving sustainable production of eggs, vol. 1. UK: Burleigh Dodds Science Publishing Limited; 2017. p. 25-48.

5. Bain M. Composition and properties of eggshell. In: Roberts JR, editor. Achieving sustainable production of eggs, vol. 1. UK: Burleigh Dodds Science Publishing Limited; 2017. p. 3-24

6. Bar A. Calcium transport in strongly calcifying laying birds: mechanisms and regulation. Comp Biochem Physiol Part A Mol Integr Physiol. 2009;152:447-69.

7. Mandal S, Lindgren AG, Srivastava AS, Clark AT, Banerjee U. Mitochondrial function controls proliferation and early differentiation potential of embryonic stem cells. Stem Cells. 2011;29:486-95.

8. Seo AY, Joseph A-M, Dutta D, Hwang JCY, Aris JP, Leeuwenburgh C. New insights into the role of mitochondria in aging: mitochondrial dynamics and more. J Cell Sci. 2010;123:2533-42.

9. Mishra P, Chan DC. Metabolic regulation of mitochondrial dynamics. J Cell Biol. 2016:212:379-87.

10. Liu R, Jin L, Long K, Tang Q, Ma J, Wang X, et al. Analysis of mitochondrial DNA sequence and copy number variation across five high-altitude species and their low-altitude relatives. Mitochondrial DNA Part B. 2018;3:847-51.
11. Fuke S, Kubota-Sakashita M, Kasahara T, Shigeyoshi Y, Kato T. Regional variation in mitochondrial DNA copy number in mouse brain. Biochim Biophys Acta Bioenerg. 2011;1807:270-4.

12. Hartmann N, Reichwald K, Wittig I, Dröse S, Schmeisser S, Lück C, et al. Mitochondrial DNA copy number and function decrease with age in the short-lived fish Nothobranchius furzeri. Aging Cell. 2011;10:824-31.

13. Khalifa ARM, Abdel-Rahman EA, Mahmoud AM, Ali MH, Noureldin M, Saber $\mathrm{SH}$, et al. Sex-specific differences in mitochondria biogenesis, morphology, respiratory function, and ROS homeostasis in young mouse heart and brain. Physiological reports. 2017:5:e13125.

14. Szczesny B, Brunyánszki A, Ahmad A, Oláh G, Porter C, Toliver-Kinsky T, et al. Time-dependent and organ-specific changes in mitochondrial function, mitochondrial DNA integrity, oxidative stress and mononuclear cell infiltration in a mouse model of burn injury. PLoS One. 2015;10:e0143730.

15. Larsen RG, Callahan DM, Foulis SA, Kent-Braun JA. In vivo oxidative capacity varies with muscle and training status in young adults. J Appl Physiol. 2009:107:873-9.

16. Jacobs RA, Lundby C. Mitochondria express enhanced quality as well as quantity in association with aerobic fitness across recreationally active individuals up to elite athletes. J Appl Physiol. 2013;114:344-50.

17. Brunk CF. Mitochondrial proliferation during myogenesis. Exp Cell Res. 1981;136:305-9.

18. Klaus S, Casteilla L, Bouillaud F, Ricquier D. The uncoupling protein UCP: a membraneous mitochondrial ion carrier exclusively expressed in brown adipose tissue. Int J BioChemiPhysics. 1991;23:791-801.

19. Poyton RO, McEwen JE. Crosstalk between nuclear and mitochondrial genomes. Annu Rev Biochem. 1996;65:563-607.

20. Bogenhagen D, Clayton DA. The number of mitochondrial deoxyribonucleic acid genomes in mouse $L$ and human HeLa cells. Quantitative isolation of mitochondrial deoxyribonucleic acid. J Biol Chem. 1974;249:7991-5.

21. Campbell CT, Kolesar JE, Kaufman BA. Mitochondrial transcription factor a regulates mitochondrial transcription initiation, DNA packaging, and genome copy number. Biochim. Biophys. Acta, Gene Regul. Mech. 2012;1819:921-9.

22. Fusté JM, Wanrooij S, Jemt E, Granycome CE, Cluett TJ, Shi Y, et al. Mitochondrial RNA polymerase is needed for activation of the origin of light-strand DNA replication. Mol Cell. 2010;37:67-78.

23. Jemt E, Persson Ö, Shi Y, Mehmedovic M, Uhler JP, López MD, et al. Regulation of DNA replication at the end of the mitochondrial D-loop involves the helicase TWINKLE and a conserved sequence element. Nucleic Acids Res. 2015;43:9262-75.

24. Westermann B. Mitochondrial fusion and fission in cell life and death. Nat Rev Mol Cell Biol. 2010;11:872-84.

25. Smirnova E, Griparic L, Shurland D-L, Van Der Bliek AM. Dynamin-related protein Drp1 is required for mitochondrial division in mammalian cells. Mol Biol Cell. 2001:12:2245-56.

26. Tieu Q, Nunnari J. Mdv1p is a WD repeat protein that interacts with the dynamin-related GTPase, Dnm1p, to trigger mitochondrial division. J Cell Biol. 2000;151:353-66.

27. Mozdy AD, McCaffery JM, Shaw JM. Dnm1p GTPase-mediated mitochondrial fission is a multi-step process requiring the novel integral membrane component Fis1p. J Cell Biol. 2000:151:367-80.

28. Falkenberg M, Larsson N-G, Gustafsson CM. DNA replication and transcription in mammalian mitochondria. Annu Rev Biochem. 2007:76:679-99.

29. Atkinson AW, John PCL, Gunning BES. The growth and division of the single mitochondrion and other organelles during the cell cycle of Chlorella, studied by quantitative stereology and three dimensional reconstruction. Protoplasma. 1974:81:77-109.

30. Posakony JW, England JM, Attardi G. Mitochondrial growth and division during the cell cycle in HeLa cells. J Cell Biol. 1977;74:468-91.

31. Tanaka K, Kanbe T, Kuroiwa T. Three-dimensional behaviour of mitochondria during cell division and germ tube formation in the dimorphic yeast Candida albicans. J Cell Sci. 1985:73:207-20.

32. Holloszy JO, Oscai LB, Don IJ, Mole PA. Mitochondrial citric acid cycle and related enzymes: adaptive response to exercise. Biochem Biophys Res Commun. 1970;40:1368-73.

33. Hood DA, Zak R, Pette D. Chronic stimulation of rat skeletal muscle induces coordinate increases in mitochondrial and nuclear mRNAs of cytochrome-coxidase subunits. Eur J Biochem. 1989:179:275-80.

34. Mogensen M, Bagger M, Pedersen PK, Fernström M, Sahlin K. Cycling efficiency in humans is related to low UCP3 content and to type I fibres but not to mitochondrial efficiency. J Physiol. 2006;571:669-81. 
35. Boushel R, Gnaiger E, Schjerling P, Skovbro M, Kraunsøe R, Dela F. Patients with type 2 diabetes have normal mitochondrial function in skeletal muscle. Diabetologia. 2007;50:790-6.

36. Drahota Z, Milerova M, Stieglerova A, Houstek J, Ostadal B. Developmental changes of cytochrome $c$ oxidase and citrate synthase in rat heart homogenate. Physiol Res. 2004;53:119-22.

37. Marin-Garcia J, Ananthakrishnan R, Goldenthal MJ. Human mitochondrial function during cardiac growth and development. Mol Cell Biochem. 1998;179:21-6.

38. Pesta D, Hoppel F, Macek C, Messner H, Faulhaber M, Kobel C, et al. Similar qualitative and quantitative changes of mitochondrial respiration following strength and endurance training in normoxia and hypoxia in sedentary humans. Am J Physiol Regul Integr Comp Physiol. 2011:301:R1078-87.

39. Tonkonogi M, Harris B, Sahlin K. Increased activity of citrate synthase in human skeletal muscle after a single bout of prolonged exercise. Acta Physiol Scand. 1997;161:435-6.

40. Siu PM, Donley DA, Bryner RW, Alway SE. Citrate synthase expression and enzyme activity after endurance training in cardiac and skeletal muscles. J Appl Physiol. 2003;94:555-60.

41. Puigserver P, Wu Z, Park CW, Graves R, Wright M, Spiegelman BM. A coldinducible coactivator of nuclear receptors linked to adaptive thermogenesis. Cell. 1998;92:829-39.

42. St-Pierre J, Lin J, Krauss S, Tarr PT, Yang R, Newgard CB, et al. Bioenergetic analysis of peroxisome proliferator-activated receptor gamma coactivators 1alpha and 1beta (PGC-1alpha and PGC-1beta) in muscle cells. J Biol Chem. 2003;278:26597-603.

43. Wu Z, Puigserver $P$, Andersson U, Zhang C, Adelmant G, Mootha V, et al. Mechanisms controlling mitochondrial biogenesis and respiration through the thermogenic coactivator pgc-1. Cell. 1999;98:115-24.

44. Lehman JJ, Barger PM, Kovacs A, Saffitz JE, Medeiros DM, Kelly DP. Peroxisome proliferator-activated receptor $\gamma$ coactivator-1 promotes cardiac mitochondrial biogenesis. J Clin Invest. 2000;106:847-56.

45. Takeyasu K, Tamkun MM, Renaud KJ, Fambrough DM. Ouabain-sensitive ( $\mathrm{Na}$ $++K+)$-ATPase activity expressed in mouse $L$ cells by transfection with DNA encoding the alpha-subunit of an avian sodium pump. J Biol Chem. 1988:263:4347-54.

46. Glynn IM. The Nat, K+-transporting adenosine triphosphatase. In: Martonosi AN, editor. The enzymes of biological membranes: volume 3: membrane transport. Boston, MA: Springer US; 1985. p. 35-114.

47. de Wit JJ, Cook JKA, van der Heijden HMJF. Infectious bronchitis virus variants: a review of the history, current situation and control measures. Avian Pathol. 2011;40:223-35.

48. Spaan W, Cavanagh D, Horzinek MC. Coronaviruses: structure and genome expression. J Gen Virol. 1988;69:2939-52.

49. Fan H, Ooi A, Tan YW, Wang S, Fang S, Liu DX, et al. The nucleocapsid protein of coronavirus infectious bronchitis virus: crystal structure of its $\mathrm{N}$ terminal domain and multimerization properties. Structure. 2005;13:1859-68.

50. Earp LJ, Delos SE, Park HE, White JM. The many mechanisms of viral membrane fusion proteins. In: editors. Membrane Trafficking in Viral Replication. Springer. 2004:25-66.

51. Gallagher TM, Buchmeier MJ. Coronavirus spike proteins in viral entry and pathogenesis. Virology. 2001;279:371-4.

52. Ignjatovic J, Galli L: Structural proteins of avian infectious bronchitis virus: role in immunity and protection. In: editors. Coronaviruses. Springer; 1994. p. 449-453.

53. Cavanagh D: The coronavirus surface glycoprotein. In: editors. The Coronaviridae. Springer; 1995. p. 73-113.

54. Chu VC, McElroy LJ, Chu V, Bauman BE, Whittaker GR. The avian coronavirus infectious bronchitis virus undergoes direct low-pH-dependent fusion activation during entry into host cells. J Virol. 2006;80:3180-8.

55. Winter C, Schwegmann-Weßels C, Cavanagh D, Neumann U, Herrler G. Sialic acid is a receptor determinant for infection of cells by avian infectious bronchitis virus. J Gen Virol. 2006;87:1209-16.

56. El Rahman SA, Winter C, El-Kenawy A, Neumann U, Herrler G. Differential sensitivity of well-differentiated avian respiratory epithelial cells to infection by different strains of infectious bronchitis virus. J Virol. 2010;84:8949-52

57. Rahman SAE, El-Kenawy A, Neumann U, Herrler G, Winter C. Comparative analysis of the sialic acid binding activity and the tropism for the respiratory epithelium of four different strains of avian infectious bronchitis virus. Avian Pathol. 2009;38:41-5.

58. Mork A-K, Hesse M, Abd El Rahman S, Rautenschlein S, Herrler G, Winter C. Differences in the tissue tropism to chicken oviduct epithelial cells between avian coronavirus IBV strains QX and B1648 are not related to the sialic acid binding properties of their spike proteins. Vet Res. 2014;45:67.

59. Raj GD, Jones RC. Infectious bronchitis virus: immunopathogenesis of infection in the chicken. Avian Pathol. 1997:26:677-706.

60. Jackwood MW, de Wit S. Infectious bronchitis. In: Swayne DE, editor Diseases of poultry. USA: John Wiley \& Sons; 2013. p. 139-60.

61. Box PG, Holmes HC, Finney PM, Froymann R. Infectious bronchitis in laying hens: the relationship between haemagglutination inhibition antibody levels and resistance to experimental challenge. Avian Pathol. 1988;17:349-61.

62. Broadfoot DI, Smith WM. Effects of infectious bronchitis in laying hens on egg production, percent unsettable eggs and hatchability. Poult Sci. 1954;33:653-4.

63. Chousalkar KK, Roberts JR, Reece R. Comparative histopathology of two serotypes of infectious bronchitis virus ( $T$ and N1/88) in laying hens and cockerels. Poult Sci. 2007:86:50-8.

64. Chousalkar KK, Roberts JR. Ultrastructural study of infectious bronchitis virus infection in infundibulum and magnum of commercial laying hens. Vet Microbiol. 2007;122:223-36.

65. Raj GD, Jones RC. An in vitro comparison of the virulence of seven strains of infectious bronchitis virus using tracheal and oviduct organ cultures. Avian Pathol. 1996:25:649-62.

66. Samiullah S, Omar AS, Roberts J, Chousalkar K. Effect of production system and flock age on eggshell and egg internal quality measurements. Poult Sci. 2016;96:246-58

67. Senne DA. Virus propagation in embryonating eggs. A laboratory manual for the isolation and identification of avian pathogens. 1998:235-40.

68. Reed $\amalg$, Muench $\mathrm{H}$. A simple method of estimating fifty per cent endpoints. Am J Epidemiol. 1938:27:493-7.

69. Chousalkar KK, Cheetham BF, Roberts JR. LNA probe-based real-time RT-PCR for the detection of infectious bronchitis virus from the oviduct of unvaccinated and vaccinated laying hens. J Virol Methods. 2009;155:67-71.

70. Peirson SN, Butler JN, Foster RG. Experimental validation of novel and conventional approaches to quantitative real-time PCR data analysis. Nucleic Acids Res. 2003;31:e73-3.

71. Samiullah S, Roberts J, Wu S-B. Downregulation of ALAS1 by nicarbazin treatment underlies the reduced synthesis of protoporphyrin IX in shell gland of laying hens. Sci Rep. 2017;7:6253.

72. Miller FJ, Rosenfeldt FL, Zhang C, Linnane AW, Nagley P. Precise determination of mitochondrial DNA copy number in human skeletal and cardiac muscle by a PCR-based assay: lack of change of copy number with age. Nucleic Acids Res. 2003;31:e61-1.

73. Khan S, Roberts J, Wu S-B. Reference gene selection for gene expression study in shell gland and spleen of laying hens challenged with infectious bronchitis virus. Sci Rep. 2017;7:14271.

74. Pfaffl MW, Horgan GW, Dempfle L. Relative expression software tool (RESTC) for group-wise comparison and statistical analysis of relative expression results in real-time PCR. Nucleic Acids Res. 2002;30:e36-6.

75. qbase+ user manual: https://www.qbaseplus.com/sites/default/files/public_ file/qbaseplus_manual.pdf. Accessed 1 May 2017.

76. Hellemans J, Mortier G, De Paepe A, Speleman F, Vandesompele J. qBase relative quantification framework and software for management and automated analysis of real-time quantitative PCR data. Genome Biol. 2007;8:R19.

77. Chousalkar KK, Roberts JR, Reece R. Histopathology of two serotypes of infectious bronchitis virus in laying hens vaccinated in the rearing phase. Poult Sci. 2007:86:59-62.

78. Williamson CD, DeBiasi RL, Colberg-Poley AM. Viral product trafficking to mitochondria, mechanisms and roles in pathogenesis. Infect Disord Drug Targets. 2012;12:18-37.

79. Hammond KA, Chappell MA, Cardullo RA, Lin R-S, Johnsen TS. The mechanistic basis of aerobic performance variation in red jungle fowl. J Exp Biol. 2000;203:2053-64.

80. Anderson RM, Barger JL, Edwards MG, Braun KH, O'Connor CE, Prolla TA et al. Dynamic regulation of PGC-1a localization and turnover implicates mitochondrial adaptation in calorie restriction and the stress response. Aging Cell. 2008;7:101-11.

81. Schreiber SN, Knutti D, Brogli K, Uhlmann T, Kralli A. The transcriptional coactivator PGC-1 regulates the expression and activity of the orphan nuclear receptor estrogen-related receptor a (ERRa). J Biol Chem. 2003;278:9013-8.

82. Puigserver $P$, Spiegelman BM. Peroxisome proliferator-activated receptor- $\gamma$ coactivator 1a (PGC-1a): transcriptional coactivator and metabolic regulator. Endocr Rev. 2003;24:78-90. 
83. Schreiber SN, Emter R, Hock MB, Knutti D, Cardenas J, Podvinec M, et al. The estrogen-related receptor a (ERRa) functions in PPARY coactivator 1a (PGC-1a)-induced mitochondrial biogenesis. Proc Natl Acad Sci U S A. 2004:101:6472-7.

84. Frank S, Gaume B, Bergmann-Leitner ES, Leitner WW, Robert EG, Catez F, et al. The role of dynamin-related protein 1, a mediator of mitochondrial fission, in apoptosis. Dev Cell. 2001;1:515-25.

85. Rajasekaran SA, Barwe SP, Rajasekaran AK. Multiple functions of $\mathrm{Na}$, K-ATPase in epithelial cells. Semin Nephrol. 2005;25:328-34.

86. Li YP, Bang DD, Handberg K, Jorgensen PH, Zhang MF. Evaluation of the suitability of six host genes as internal control in real-time RT-PCR assays in chicken embryo cell cultures infected with infectious bursal disease virus. Vet Microbiol. 2005;1 10:155-65.

87. Bagés S, Estany J, Tor M, Pena RN. Investigating reference genes for quantitative real-time PCR analysis across four chicken tissues. Gene. 2015;561:82-7.

88. Kheravii SK, Swick RA, Choct M, Wu S-B. Upregulation of genes encoding digestive enzymes and nutrient transporters in the digestive system of broiler chickens by dietary supplementation of fiber and inclusion of coarse particle size corn. BMC Genomics. 2018;19:208.

Ready to submit your research? Choose BMC and benefit from:

- fast, convenient online submission

- thorough peer review by experienced researchers in your field

- rapid publication on acceptance

- support for research data, including large and complex data types

- gold Open Access which fosters wider collaboration and increased citations

- maximum visibility for your research: over $100 \mathrm{M}$ website views per year

At $\mathrm{BMC}$, research is always in progress.

Learn more biomedcentral.com/submissions 